\title{
IMPROVING STUDENTS' MOTIVATION AND READING SKILLS IN ELT THROUGH AUDIO VISUAL MEDIA
}

\author{
Agus Husein As Sabiq \\ MTs Al Iman Purworejo \\ email: guzenaby@gmail.com
}

\begin{abstract}
This research aims to describe: (1) the use of audio-visual media in teaching and learning in English class, (2) the use of audio-visual media in improving the motivation and reading skills of the seventh grade students of MTs Al Iman Purworejo. This research is classroom action research which used Kemmis \& McTaggart model with two cycles. The subjects were students of class VII D of MTs Al Iman Purworejo in the academic year of 2014/2015. The objects were the audio-visual media, and students' motivation and reading skills in English. The results of this study show that the use of audio-visual media improved $90 \%$ of the students to have a high motivation in English class that includes attitude, interest, and effort in learning English. In addition, the use of audio-visual media also improved $83 \%$ of the students to gain their reading skills achievement of descriptive text to get scores higher than the minimum standards. The result of the pretest showed $57 \%$ of students had high motivation, in the first cycle there were $70 \%$ of students who had high motivation, and in the second cycle there were $90 \%$ of students who had high motivation. The students' reading skill also improved; in the initial test $48 \%$ of students had scores higher than the minimum standard; in the first cycle, there were $65 \%$ of students having scores higher than the minimum standard, and; in the second cycle, there were $83 \%$ of students having scores higher than the minimum standard. Thus, it can be concluded that the use of audio-visual media can improve the motivation and reading skills in English lessons of class VII D students' of MTs Al Iman Purworejo.
\end{abstract}

Keywords: motivation, reading skill, audio-visual media

\section{MENINGKATKAN MOTIVASI DAN KETERAMPILAN MEMBACA SISWA PADA PENGAJARAN BAHASA INGGRIS MELALUI MEDIA AUDIO-VISUAL}

\begin{abstract}
ABSTRAK
Penelitian ini bertujuan untuk mendeskripsikan: (1) penggunaan media audiovisual dalam proses belajar mengajar di kelas bahasa Inggris, (2) penggunaan media audiovisual dalam meningkatkan motivasi dan kemampuan membaca siswa kelas VII MTs Al Iman Purworejo. Penelitian ini adalah tindakan kelas yang menggunakan model Kemmis \& McTaggart dengan dua siklus. Subjek penelitian adalah siswa kelas VII D MTs Al Iman Purworejo tahun akademik 2014/2015. Objek penelitian ini adalah media audio-visual, motivasi dan kemampuan membaca siswa pada pelajaran bahasa Inggris. Hasil penelitian ini menunjukkan bahwa penggunaan media audio-visual meningkatkan 90\% dari siswa untuk memiliki motivasi tinggi terhadap kelas bahasa Inggris yang meliputi sikap, keinginan, dan usaha dalam belajar bahasa Inggris. Selain itu, penggunaan media audio-visual juga meningkatkan $83 \%$ dari siswa untuk mendapatkan prestasi kemampuan membaca pada teks deskripsi dengan mendapatkan nilai lebih dari standar minimal. Pada uji awal, 57\% siswa memiliki motivasi tinggi, pada siklus pertama terdapat $70 \%$ siswa memiliki motivasi tinggi, dan pada siklus kedua terdapat $90 \%$ siswa memiliki motivasi tinggi. Kemampuan membaca siswa juga mengalami peningkatan dimana pada tes awal terdapat $48 \%$ siswa mendapat nilai diatas standar minimal, pada siklus pertama terdapat $65 \%$ siswa mendapat nilai diatas standar minimal, dan pada siklus kedua terdapat $83 \%$ siswa mendapat nilai diatas standar minimal. Dengan demikian disimpulkan bahwa penggunaan media audiovisual dapat meningkatkan motivasi dan keterampilan membaca pada pelajaran bahasa Inggris siswa kelas VII D MTs Al Iman Purworejo.
\end{abstract}

Kata Kunci: motivasi, keterampilan membaca, media audio-visual 


\section{INTRODUCTION}

Motivation to learn is the heart of learning activities. Motivation to learn is the driving force that affects whether or not the hard efforts to learn made by the students. Elliot et.al. (2000: 332) stated that motivation is defined as an internal state that arise us to action, pushes us in particular directions, and keeps us engaged in certain activities. Learning and motivation are equally essential for performance: learning enables us to acquire new knowledge and skills, and the motivation provides the impetus for showing what we have learned. In general, moremotivated people achieve at higher levels.

High motivation to learn is reflected in the persistence that is not easily broken to achieve success despite the difficulties faced by many. High motivation can encourage student learning activities. That is not an easy task since motive is an internal process that energizes and directs behavior (Reeve, 2009: 10). However, he added that motivation can be inferred from its expression through person's behavior, engagement, psychology and selfreport. High motivation can be found in the nature of student behavior among these qualities, the high student involvement in the study, the presence of affective feelings and high student engagement in learning, student effort to continually maintain or keep to always choosing a high motivation to learn. Motivation to learn is needed in the classroom.

Motivation in foreign language learning had been considerations for the teachers nowadays. English is one of the subjects for students of junior high school. This subject requires them to learn at least four hours per week. They are prepared to be able to communicate with other people around the world. Hence, they must study English in their schools.

One of very important skills that must be mastered by the students of junior high school is reading. By reading, they make sense what a writer means. They can also catch the information in a text even the detail information. A text can be a good model to learn English because it provides structures and information to support their learning. According to Pang (2003: $6)$, reading consists of two related processes: word recognition and comprehension. Word recognition refers to the process of perceiving how written symbols correspond to one's spoken language. Comprehension is the process of making sense of words, sentences, and connecting text. Readers typically make use of the background knowledge, vocabulary, grammatical knowledge, experience with the text and other strategies to help them understand written text.

In the academic year 2014/2015, MTs Al Iman Purworejo implement curriculum 2013. According to the syllabus of curriculum 2013, descriptive text becomes the genre of the text that has to be taught in the seventh grade. It discusses the description a particular person, animal, place, or thing. According to Anderson (1998: 26), the purpose of descriptive text is to tell about subject by describing the characteristic without including personal opinions, the example of descriptive text is description of particular building, description of a specific animal, description of a particular place, and description of a specific person. Descriptive text has generic structure as below: (1) identification; identifying the phenomenon to be described. (2) description; describing the phenomenon in parts, qualities, and characteristics.

In English class, the students of class VII $\mathrm{D}$ are considered having low motivation. They feel bored in the class when the lesson starts. It can be called that they have low motivation in English class. However, students' motivation in learning process has very important role in the development of self. Usually, a child who does not have the motivation, he may not move on. So that students who perform activities continually will get the desired learning achievement.

Some students of class VII D feel less enthusiastic or not motivated when they are in English classroom due to methods and instructional strategies used by teachers who are still monotonous and conventional. The English teacher in MTs Al Iman Purworejo is still straight forward in teaching and learning process. It is understandable because most of the students think that the important for them is how to pass the exam. As what the famous proverb says "Do not give your students fish, 
but teach them how to fish" is perhaps true in language teaching.

Often, many teachers are found drilling the students with continuous grammatical exercises especially at the primary school level (sometimes done by the English teacher in MTs Al Iman Purworejo). Despite exposure to training in the communicative approach, teachers may still avoid practicing the approach because the communicative component, i.e. oral communication that makes up only ten percent of the exam scores on the English test. In other words, many teachers are interested in training students read and write well in addition to teaching students to master the grammar component of the language.

There are also some problems faced by the teacher in teaching descriptive text in Islamic Junior High School Al Iman. One of them is that the teacher couldn't give the students more real examples. The teacher teaches what is cited in the text book. He fails to give more information to make the students easy to understand. Besides, the teacher uses text book and work book to become media in learning. He realizes that most of the students get difficulties to understand the text and get the information of it. It is because the teacher provides less real examples and other media to deal with it.

To support the implementation of the curriculum 2013, the presence of learning media is needed, especially in language learning. Smaldino, et.al. (2005: 9) said that a medium (plural, media) is a means of communication and source of information. It is derived from the Latin word meaning "between" the term refers to anything that carries information between a source and a receiver for example video, television, diagrams, printed materials, computer programs, and instructors. Teaching and learning activities will be effective and efficient if the activity is accompanied by the use of media as a learning tool.

The presence of the media especially technological media is assisting the teacher in delivering the message of the lesson material that will be presented by the teacher to the learner. Educational technology refers to the use of any technology in classroom which helps in increasing the space of learning and results in helping teacher to teach less and learner to learn more (Singh, Sharma, and Upadhya, 2008: 2). But in reality, the English teachers in MTs Al Iman Purworejo are not enough of using technological media in their teaching and learning. They still use textbook and students work sheet as their instrumental teaching and learning. So, the learning materials are difficult to understand by each learner particularly complex and complicated learning materials.

In early years the only term used for teaching media was audio-visual media but with the advancement and opening of new horizons in the field of electronic technology and communication media. Khan (2013: 13) said that audio-visual media are the tools that make teaching-learning process more efficient and effective. Students do believe that they enjoy teaching through these tools as it totally changes the atmosphere of the class and makes the class more interactive.

According to Lavin et.al. (2010: 1) the use of audio-visual media makes the students more attentive in class and prepares them for class well. They prove to be a very positive tool that is responsible for easy learning. The main advantage of them is they are very helpful in easy transfer of learning and makes the learning long-lasting in the minds of students. They play a major role in student's attentiveness as use of animations, video-clippings etc. help them to motivate well which in turn make them sit in the class for longer duration.

Eventually, students' low motivation and uninterested learning media affect their learning achievement in English. The teacher reports that there are still only $30 \%$ of the students who have score higher than the standard minimum score. The students just hear the teacher's speech in their learning process because the teacher fails to use the appropriate media in teaching learning process. As mention above that there are found many teacher drilling the students with exercises, but it is not effective to increase students' achievement in English because they do not get more exposure of English. In this case, the need of appropriate learning media that is interesting to students' attention to get more exposure is a must to be implemented. 
The formulation of the problems in this research are (1) How is the English learning process using audio-visual media in MTs Al Iman Purworejo carried out in reference to the staged, goal-oriented, and classroom action research activities? (2) How is the use of audiovisual media performed in improving students' motivation in English teaching and learning process at MTs Al Iman Purworejo? (3) How is the use of audio-visual media performed in improving students' reading skill on descriptive text at MTs Al Iman Purworejo?

The findings of this classroom action research were expected to give some contributions for the English teachers, the students, the principal, and the other researchers. For English teachers, this research hopefully encourages them to seek and choose the best methods and strategies of teaching English for their students. For the principal, the result of this research is wished to contribute ideas for the principal in promoting the quality of teaching and learning in MTs Al Iman Purworejo through audio-visual media. For the students, this research can encourage them to improve their motivation and achievement in English language. The implementation of audio-visual media can facilitate the students with better opportunities to learn English collaboratively through various kinds of activities like reading a lot of books, sharing ideas, and listening others. For the other researchers, this research may not be perfect yet, however, it may be an entrance gate to do a more innovative research in improving the teaching and learning process, and finally it may give contribution to the development of language teaching and learning.

\section{METHOD}

This research was a classroom action research by using a qualitative approach. It was the research used as a measuring tool for teachers dealing with their own teaching process. It was also used to measure how effective the method they use in helping the students to learn the material.

Burns (1999: 32) states that action research occurs through a dynamic and complementary process, which consist of four essential "moments": of planning, action, observation and reflection. This classroom action research is designed in Kemmis \& McTaggart's model which involved a set of steps in repeated cycles as set out in the figure below:

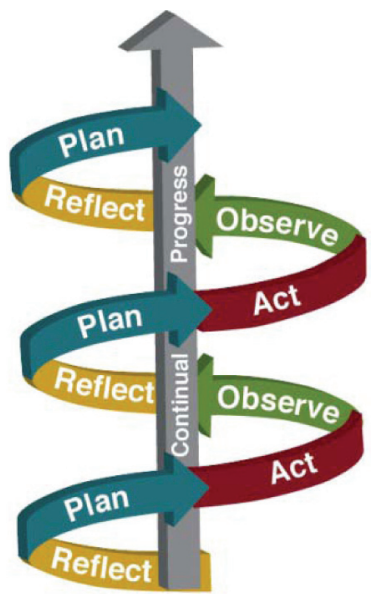

Figure 1. The Action Research Spiral

This action research had been conducted in MTs Al Iman Purworejo which was located on Jl. Ngadipurwo Bulus Gebang in the regency of Purworejo and in the Province of Jawa Tengah. The students of class VII D had been chosen to be the subjects of the study. This research had been carried out on the second semester in academic year 2014/2015 which took a month to implement the use of audio-visual media.

This classroom action research had been used to solve the problems faced by the students of grade VII D of MTs Al Iman Purworejo. The subjects of the research assumed getting the lower progress on their motivation in English class. However, MTs Al Iman Purworejo separated the classes between boys and girls because it was under the foundation of Al Iman Islamic Boarding. The subjects of the research were students of grade VII D which all of them were girls. Their ages range between 11 and 13 . As this action research aimed at using audiovisual media to increase students' motivation and their reading skill on descriptive text in English class among grade VII D of MTs Al Iman Purworejo, the objects of this research were the audio-visual media, students' motivation and students' reading skill.

According to McNiff (2002: 76) there were various traditional methods in data collection procedure like personal field 
notes, audio tape recording, pupil diaries, interviews and discussion, videotaped recording, questionnaires, documentary evidence, and slide/tape photography. In gathering the data in this research, it used some techniques and instruments. They were direct observation, interview, questionnaire, and test. The instruments of direct observation were the form of observation sheet and field notes which are used to record what happen in the classroom. The data gathered using these instruments had been used as a preliminary data to design the technique applied in each cycle.

The interviews were supported by the use of existing media such as digital camera and audio recorder. It was to figure out what the students want, need, and feel in teaching learning process. Besides, it was able to find out the problems that the students face in undergoing the teaching and learning process. As the result, it was able to improve the way of teaching and also the students' interest and motivation.

Like the interviews, the questionnaire was used to gather the data of the progress of the students' motivation. The items of the questionnaire will use Attitude/Motivation Test Battery which is developed by Gardner (2004: 1-4). The items consisted of interest in English, motivational intensity, desire to learn English, and orientation index.

Test was a set of questions and exercises used to measure the achievement or capability of the individual or group. It was perhaps the most common tools used to collect data by action researchers. In this action research, the researcher used achievement test because it was made to measure the students' reading skill after they had learned the material. According to Brown (2001: 391), an achievement test is related directly to classroom lessons, units, or even a total curriculum. Achievements tests are limited to particular material covered in a curriculum within a particular time frame, and are offered after a course has covered the objectives in question. Achievement tests can serve as indicators of features that a student needs to work on in the future, but the primary role of an achievement test is to determine acquisition of course objectives at the end of period of instruction.
The test itself was administered one time in every cycle. A standard technique should be used to show that results of research were reliable to measure the reading test.

It was noteworthy that action research was a cyclical process and a reflexive process in which the data analysis was done within the investigation. However, there were certain stages must be done in order to analyze the data. They were stated by McKernan (1996) in Burns (1999: 157-160). The first step was assembling the data. The data had been gathered during the action process. In gathering the researcher used the field notes and observation sheets during the teaching learning process. It was also used the interviews guideline to get the data from the teacher and students. The last one, the researcher used questionnaire to get the data of the students' motivation and its improvement in every cycle. Those data were read by scanning technique. While doing the scanning, note taking was also used to write what was impressed during this process.

Second step was coding the data that was used in order to reduce distracting data and to arrange and categorize the data being gathered. In this stage, it had been given codes to the students' interview script, the result of questionnaire, and the result of evaluation. The data were classified whether it was related to the study or not. It was aimed at simplifying the process of reading and analyzing the data.

Comparing the data became the next step. Comparison was done in order to see whether certain patterns are repeated or developed across different data gathering techniques. In this stage, the data that had been categorized and classified were read over and over again to make sure that there would not be redundancy within the data and report. It was aimed to make easy in building interpretation.

The last step was building interpretation. The data that had been categorized and compared from interview script, field notes, observation sheets, and questionnaire were analyzed in building the interpretation. The students' motivation also had been observed through their physical performance, attitude, and engagement during their learning in the class. The students' performance was viewed through their: attention 
to the teacher, enjoyment in the teaching and learning process, enthusiasm in doing the task given, persistence in learning, effort to do the task, latency in performing the task, and decrease of the students' tension.

The data of reading skill improvement were analyzed from the result of evaluation test. By doing that, it was expected that it was able to make an objective judgment over the data gathered. Also, it was tried to sum up all the report shown by the instruments in order to be sure that it made a wrong interpretation.

\section{Criteria for success}

The success of this action research was indicated by the raise of the students' motivation and improvement on reading skill achievement that were indicated by their behavior changes during the learning process and test score of every cycle. Those changes were seen through students' behavioral change and students' engagement, students' self-report, and students' test score.

The students' behavioral change and engagement were assessed during the teaching and learning process. It was actually hard to measure the motivational improvement of the students since it happened inside them. However, it was inferred with the collaborator about those changes by classifying and monitoring the students' behavior. Then, it was made percentage of the score they got. By doing that, it was found the motivational improvement made by the students.

Dealing with the students' engagement, it was counted also their frequency of being active during the learning process. The students who were motivated became more active in performing what they had learned during the learning process. If the more participation was witnessed, it was assumed that they had experienced motivational improvement and the effort in increasing students' motivation was considered to be success.

As was stated previously that the easiest way to know what the students think was simply by asking questions. So, this research was considered to be success if they admitted they liked the activities given, no longer bored during the learning process, enjoyed the learning, and stated they wanted to learn more English by doing more practice and task given at once enthusiastically.

The score was conducted by doing test. The research was considered to be success if $80 \%$ of students got the score higher than standard minimum score which is 71 .

\section{FINDINGS AND DISCUSSION}

The reconnaissance was done a set of activities like conducting preliminary observation in the classroom during the teaching practice, interviewing the students and teacher, questionnaire, pretest, and taking notes. The reconnaissance was divided into two categories; the students' motivation toward English and students' reading skill. The researcher used questionnaire to find out whether or not the students' motivation was low. The questionnaire was adopted from Attitude/Motivational Test Battery by Gardner (2004). The questionnaire included attitude toward English, motivational intensity, desire to learn English, and orientation index.

The discussion with the collaborators resulted in conclusion that the students faced ten problems to take into account. The problems were then classified according to the elements of motivations into three elements namely 1) the attitude towards learning English (affect), 2) motivational intensity (effort), and 3 ) the desire to learn English (want). The classification was done as in the following table 1.

In order to support the data on the students' motivation before the action research, a preliminary measurement on the students' motivation was done on $24^{\text {th }}$ April 2015. The questionnaire was developed from the three elements of motivation; students' attitude toward English class, motivational intensity, and desire to learn English. The questionnaire was also equipped with statements which indicated the students' orientation in learning English.

The score of students' motivation which was made of students' attitude towards English, students' motivational intensity, and students' desire to learn English was classified into poor, low, fairy, high, and very high. The following table describes the score of students' motivation. 
Table 1. The Classification of the Problems in the Reconnaissance

\begin{tabular}{lll}
\hline No & \multicolumn{1}{c}{ Elements } & \multicolumn{1}{c}{ Problems } \\
\hline & 1. The students found that the text book-based learning was \\
English (affect) & not attractive.
\end{tabular}

Table 2. The Classification of Students' Motivation on Preliminary Research

\begin{tabular}{ccc}
\hline Range & Classification & Sum of Students \\
\hline 5.0 to 5.9 & poor & 0 \\
6.0 to 6.9 & low & 2 \\
7.0 to 7.9 & fairy & 17 \\
8.0 to 8.9 & high & 20 \\
9.0 to 9.9 & very high & 1 \\
\hline
\end{tabular}

From 40 students, there were 2 students (3\%) who low motivation, 17 students (42\%) who have fairy motivation, 20 students $(54 \%)$ who have high motivation, and 1 student (3\%) who have very high motivation. However, it was expected at last that $80 \%$ of students possessed high motivation towards English.

The test on students' orientation index indicated that most of the students' orientations were on instrumental motivation. It was found that 23 students possessed instrumental motivation and 17 students possessed integrative motivation.

Pretest was done in order to conduct the students' skill in reading descriptive text. The pretest consists of 50 questions that have been tested to the students to get the real information about their reading skills before treatment. The chart below describes the result of the pretest.

Table 3. The Result of Students' Pretest

\begin{tabular}{lccccc}
\hline & N & Min. & Max. & Mean & Std. Dev. \\
\hline Students' & 40 & 22.00 & 86.00 & 64.75 & 17.32162 \\
Pretest & & & & & \\
Valid N & 40 & & & & \\
\hline
\end{tabular}

From the table above, it can be concluded that the average score of students' pretest is 64.75 . There were 21 students who have the scores under the minimum standard i.e. 71. It means that $52 \%$ students have the scores under the minimum standard and $48 \%$ students who have the scores up the minimum standard. However, it was expected that there would be at least $80 \%$ students who have the scores up the minimum standard after the treatment.

\section{First cycle}

There were four big things to reflect in the discussion as follows. First, the first cycle was the introduction of descriptive text and how to describe someone or something. The text was very simple description. In order to get the clear example, the teacher used interesting picture and video to get more attention from the students. However, the students tent to enjoy the picture and video rather than the essence of both to make easy for them to understand. So, the students sometimes confused whenever the teacher asked them because they were too focus on the picture or video not on the sentences, phrases or expression.

Second, the students were guided to observe, ask, analyze, and communicate their ideas or observation. Those made them enjoy the learning process. They preferred to go around the class or out of the class to observe or search information rather than sit on the chair in silent and just listen to the teacher explanation or do the task. 
Third, one of the activities done was sharing their ideas in front of the class. The students were still afraid to make mistakes. They were unconfident to speak. However, the teacher tried to support them in which the teacher did not make under pressure to be always right. Sharing ideas in front of the class was actually more effective facilitating the students with more chances to use English as means of communication.

Fourth, one of the problems that the students faced in reading text was lack of vocabulary. They tent to ask the teacher or opening vocabulary whenever they did not know a particular word in English. The pictures and the video were very helpful for them in understanding the meaning of some words.

The average of the questionnaire scores indicated that using audio-visual media had made changes on the students' motivation. The changes on the motivational states were indicated by the increase on the average score on students' attitude, motivational intensity, desire to learn English, and also the students' orientation. The following table shows the change of the motivational states of the students.

Table 4. The Progress of the Average Score of the Students' Motivation on the First Cycle

\begin{tabular}{cccc}
\hline \multirow{3}{*}{ Cycles } & \multicolumn{3}{c}{ Average Score } \\
\cline { 2 - 4 } & $\begin{array}{c}\text { Students' } \\
\text { Attitude }\end{array}$ & $\begin{array}{c}\text { Motivational } \\
\text { Intensity }\end{array}$ & $\begin{array}{c}\text { Desire to } \\
\text { learn }\end{array}$ \\
\hline Pre. & 7.73 & 7.68 & 7.63 \\
Cycle 1 & 8.05 & 8.03 & 7.94 \\
\hline
\end{tabular}

There was a change on the students' orientation from instrumental motivation to integrative motivation. $40 \%$ of the students had instrumental motivation while $60 \%$ of the students had integrative motivation. Compared to the preliminary findings on the students' orientation, it was found that the instrumental motivation moved from $57 \%$ to $40 \%$ of the students while the integrative motivation of the students moved from $47 \%$ to $60 \%$.

Finally the classification of the students' scores on motivation can be seen on the following table.
Table 5. The Classification of the Students' scores on Motivation

\begin{tabular}{ccc}
\hline Range & Classification & Sum of Students \\
\hline 5.0 to 5.9 & poor & 0 \\
6.0 to 6.9 & low & 0 \\
7.0 to 7.9 & fairy & 11 \\
8.0 to 8.9 & high & 28 \\
9.0 to 9.9 & very high & 1 \\
\hline
\end{tabular}

According to the classification of the scores on motivation, it was found that there were 11 students $(27 \%)$ with fairy motivation states, 28 students (70 \%) with high motivation states, and 1 student ( $3 \%$ ) with very high motivation states. However, as the percentage of the students with high and very high motivation was $73 \%$, it meant that the following cycles needed to be conducted to reach $80 \%$.

The test had also been done in order to conduct the students' improvement in reading skill. The test consisted of 25 multiple choice questions. The following chart describes the result of the test by the end of the $1^{\text {st }}$ cycle.

Table 6. The Result of Evaluation Test in the $1^{\text {st }}$ cycle.

\begin{tabular}{lccccc}
\hline \multicolumn{5}{c}{ Descriptive Statistics } \\
\hline & N & Min. & Max. & Mean & Std. Dev. \\
\hline $1^{\text {st }}$ Cycle & 40 & 52.00 & 88.00 & 73.82 & 9.54312 \\
Test & & & & & \\
Valid N & 40 & & & & \\
\hline
\end{tabular}

From the table above, it could be concluded that the average score of students' test was 73.82. There were 14 students who have the scores under the minimum standard i.e. 71. It meant that $35 \%$ students had the scores under the minimum standard and $65 \%$ students who had the scores higher than the minimum standard. However, it was expected that there would be at least $80 \%$ students who have the scores higher than the minimum standard after the treatment. So, it was needed to hold the next cycle.

\section{Second cycle}

There were some findings to highlight from the reflection. Based on the result of the second cycle, the students showed better progress 
when they were asked to work in groups. Most of them showed enjoyment in doing the task and confidence in communicating the task. In addition, they were no longer afraid or doubt to share their ideas in classroom. The presence of teacher became accustomed according to the students. It would positively affect students' attitude towards English. As the result, their willingness and motivation to learn would certainly improve. However, learning was not only about enjoyment to the activities, but also it took focus and concentration. Therefore, if the teacher could manage them all and combine them in a symphony, then, like an orchestra, students' language mastery will be as beautiful as the song played in the orchestra.

The students felt that audio-visual media was very helpful to understand the material given. It was like a bridge to get real understanding. Also, the students get further information from the video they watched. Besides the audio-visual made them refreshing their mind, it also provided them the real example of description of someone, animals, or things.

The teacher said that the students, in the second cycle, became more active in joining learning activities. It was proved that the students did the task more serious. They tried to finish the task as fast as possible. And also they asked to the teacher to check and correct their works. Whenever the students were asked to share their works by writing in the whiteboard, they scramble to be the first.

The result of the assessment on the students' motivation indicated that the students' motivation increased in the three elements of motivation. The summary of the result can be seen on the following table.

Table 7. The Progress of the Average Score of the Students' Motivation on the First Cycle and the Second Cycle

\begin{tabular}{cccc}
\hline \multirow{2}{*}{ Cycles } & \multicolumn{3}{c}{ Average Score } \\
\cline { 2 - 4 } & $\begin{array}{c}\text { Students' } \\
\text { Attitude }\end{array}$ & $\begin{array}{c}\text { Motivation } \\
\text { Intensity }\end{array}$ & $\begin{array}{c}\text { Desire to } \\
\text { Learn }\end{array}$ \\
\hline Cycle 1 & 8.05 & 8.03 & 7.94 \\
Cycle 2 & 8.22 & 8.24 & 8.11 \\
\hline
\end{tabular}

The students' orientation toward learning English in the classroom also changed. In the preliminary research, it was found 23 students with instrumental orientation, in the first cycle 16 students possessed instrumental orientations and in the end of the second cycle 11 students with instrumental orientations. From the calculation, it can be concluded that the students' instrumental orientations decrease through the audio-visual media. On the other hand, the students with integrative orientation increased during the implementation of audiovisual media. It was found that in the preliminary research, there were 17 students have integrative orientation, in the first cycle there were 24 students, and in the end of second cycle there were 29 students.

The analysis of the distribution score on the students' motivation revealed that there were 4 students $(10 \%)$ with fair motivation states, 33 students $(82 \%)$ with high motivation states, and 3 students $(8 \%)$ with very high motivation states. The percentage of the students with high and very high motivation states was $90 \%$ as presented in the following table.

Table 8. The Second Cycle Distribution Score of the Students' Motivation

\begin{tabular}{ccc}
\hline Range & Classification & Sum of Students \\
\hline 5.0 to 5.9 & poor & 0 \\
6.0 to 6.9 & low & 0 \\
7.0 to 7.9 & fairy & 4 \\
8.0 to 8.9 & high & 33 \\
9.0 to 9.9 & very high & 3 \\
\hline
\end{tabular}

The result of the test in the second cycle also proved that there was an improvement of students' reading skill. The test consisted of 25 multiple choice questions. The following chart describes the result of the test by the end of the $2^{\text {nd }}$ cycle.

Table 9. The Result of Evaluation Test in the 1 st cycle.

\begin{tabular}{lccccc}
\hline & $\mathrm{N}$ & Min. & Max. & Mean & Std. Dev. \\
\hline $2^{\text {nd }}$ Cycle & 40 & 65.00 & 90.00 & 78.50 & 6.66795 \\
test & & & & & \\
Valid N & 40 & & & & \\
\hline
\end{tabular}


From the table above, it could be concluded that the average score of students'test in the $2^{\text {nd }}$ cycle was 78.50 . There were 7 students who had the scores under the minimum standard i.e. 71 . It meant that $17 \%$ students had the scores under the minimum standard and $83 \%$ students who had the scores higher than the minimum standard. It proved that the treatment was success in which the students having the scores higher than the minimum standard were more than $80 \%$ as it was expected in this research.

\section{Discussion}

After passing the two cycles in the classroom action research, some findings of the study were drawn to the present of the results of the study. The implementation of the audio-visual media as alternative media used in English class had two benefits on the improvements of the students' motivation and their reading achievement.

First, the use of audio-visual media was effective in promoting students' motivation in learning English. The students' felt that they enjoyed learning in the class because they can refresh their mind by watching video or interesting pictures. They felt that they were not bored or sleepy anymore during the learning activities. They were challenged to observe, analyze, and communicate their ideas. Besides, they were motivated to be part in every learning activity.

Second, according to the teacher, the students seem to be more active in the class. They paid more attention to the teacher, the materials, and the learning activities. When they were asked to be volunteer, they scrambled to the first student who was pointed by the teacher to do the task in front of the class. When the teacher gave them some questions, there were not one or two students who raised their hands anymore, but there were more than five ten students wanted to answer the questions. It was never happened before. They were enthusiastic to join the activities and do the task given. Moreover, they enjoyed working in collaborative groups that they were challenged to do the best than the other groups.

Third, their last achievement test showed that there was an improvement in their reading skill in descriptive text. They thought that audio-visual media made them easy to understand the material. They could find the real example and got the information to broaden their ideas. Furthermore, they learnt how to observe and be careful to read the text. They also could get the meaning of the text trough audio-visual media. In last, they could easy to understand the information in reading descriptive text.

Fourth, learning activities during the implementation of audio-visual media became more interesting and fun. When the students enjoyed the learning activities, the atmosphere in the class also became easy to be controlled.

At the evaluation of every cycle, the implementation of audio-visual media was asked to evaluate it by responding to the two open-ended questions. The first question asked whether they had enjoyed the learning process and why or why not. The second one asked whether the implementation of audio-visual media helped them to understand the material.

The responses from the students were largely positive. First, the students were experienced to practice their English. They had more time to explore their ideas because they were invited to be more active in the class.

"Pembelajaran seperti itu tentu akan membuat setiap jengkal pembelajaran dapat tertangkap dengan jelas antara materi dengan bagaimana cara mengamalkannya dan tentu saja pembelajaran seperti ini mengundang anak untuk selalu aktif"

Second, the students felt that they could have fun in the class while joining the activities. Even though, through audio-visual media they could be easy to understand the material given. They also were experienced to learn how to socialize with their friends.

"Dengan cara pembelajaran menggunakan video dan gambar bisa lebih mudah dipahami dan bisa buat hiburan. Dengan belajar kelompok, kita bisa lebih belajar bersosialisasi. Pokoknya seru deh!!!"

Third, the activities in the class became more interesting and they felt that they were not 
bored and sleepy again in the class. It happened because they could join the activities more active than before.

"Dengan bermacam-macam media yang diberikan pelajaran bahasa Inggris jadi lebih mudah dipahami dan siswa menjadi aktif dengan bermacammacam media dan metode yang menarik ini. Selain itu, kegiatan belajar bahasa Inggris lebih menyenangkan dan siswa tidak merasa jenuh ataupun bosan dengan kegiatan bahasa Inggris"

The impacts of the use of audiovisual media on the progress of the students' motivation were also indicated by the progress on the average scores of the motivation. The results of the average distribution scores showed that the students' motivation increased from preliminary study, $1^{\text {st }}$ cycle, and $2^{\text {nd }}$ cycle.

The result of the test also improved in every evaluation held. The average test score in the preliminary research was 64.75 , while in the first cycle was 73. 82, and in the second cycle was 78.50. The progress of the students' achievement test in reading descriptive text from preliminary research to first cycle was 9.07 points, and the progress from first cycle to second cycle was 4.67 points. In the preliminary research, there were 19 students (52\%) who got scores higher than the minimum standard score, while in the first cycle there were 26 students $(65 \%)$ who got scores higher than the minimum standard score, and in the second cycle there were 33 students $(83 \%)$ who got scores higher than the minimum standard score.

Finally, it was concluded that the use of audio-visual media promoted the students' attitude, want, effort, and achievement in reading descriptive text as well as to stimulate the character buildings of the students through the learning activities. The implementation of audio-visual media brought impacts on the achievements of the students' affective domains which affected the students' achievements in other two domains; cognitive and psychomotor domains which resulted on the students' high quality outcomes.

\section{CONCLUSION}

Based on the literature review, the method, findings, and discussion, it can be concluded some detailed impacts on the students' motivation and reading skill improvement that were indicated as follows.

Firstly, students found that learning through audio-visual media was very interactive and exciting. They got refreshing while learning

Table 10. The Progress of Elements of Motivation

\begin{tabular}{lccc}
\hline \multicolumn{1}{c}{ Elements of Motivation } & Preliminary Research & $\mathbf{1}^{\text {st }} \mathbf{C y c l e}$ & $\mathbf{2}^{\text {nd }} \mathbf{C y c l e}$ \\
\hline Students' Attitudes & 7.73 & 8.05 & 8.22 \\
Motivation Intensity & 7.68 & 8.03 & 8.24 \\
Desire to Learn & 7.63 & 7.94 & 8.11 \\
Instrumental Motivation & 23 Students & 16 Students & 11 Students \\
Integrative Motivation & 17 Students & 24 Students & 29 Students \\
\hline
\end{tabular}

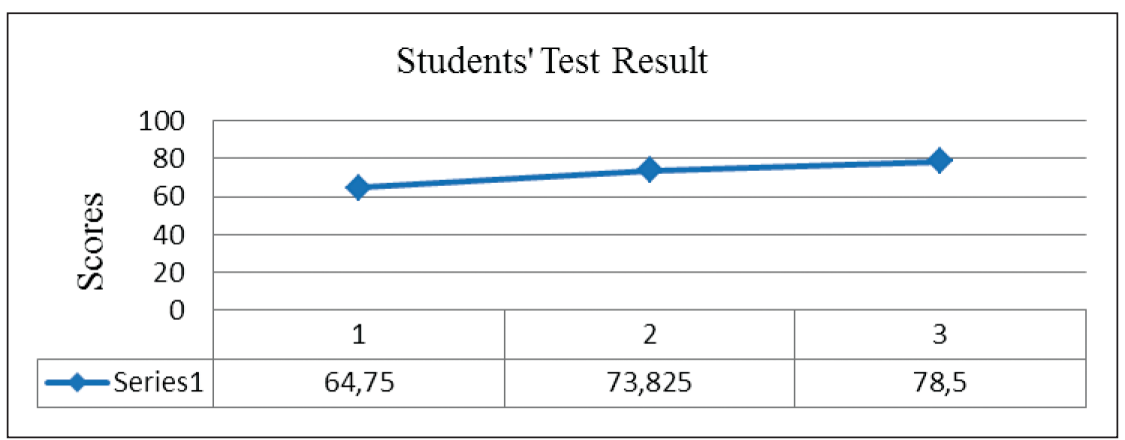

Chart 1. The Progress of Students' Achievements of Reading Descriptive Text 
because they could watch interesting pictures and videos. They enjoyed the activities done in learning process. Also, they became more confident to communicate their ideas or observation without being afraid of making mistakes. They consciously integrated themselves to the English speaking community. Therefore, their orientation changed gradually from instrumental to integrative motivation that it comes from the joy or pleasure derived through language learning process.

Secondly, the activities in implementing audio-visual media also promoted the students' motivational intensity. The students were guided to be more active in joining the activities in the class. They were guided to observe, ask, analyze and communicate their findings of the task. Besides, they also were guided share their ideas during the learning process. By doing task in pair or in group, the students learned to collaborate with other students and made them to be more communicative and cooperative. Therefore, it could make them to use English as means of communication.

Thirdly, as the theory that in language learning, learners use their eyes as well as their ears; but their eyes are basic in learning. All audio-visual materials have positive contributions to language learning as long as they are used at the right time and the right place. The use of audio-visual media helped the students to get better understanding to the material. They thought that audio-visual media made them easy to understand especially in reading descriptive text because it provided the real and interesting examples. So that they got ideas and information from the media used. Therefore, they were stimulated to learn English better. The audio-visual media stimulated them to open their minds and share their ideas. They became more familiar with the model and the structure of descriptive text, so they could gain their reading skill.

\section{REFERENCES}

Anderson, M. and Anderson, K. 1998. Text Type in English 3. Australia: Macmilan

Burns, A. 1999. Collaborative Action Research for Language Teacher. Cambridge: Cambridge University Press.

Elliott, S. N., et.al. 2000. Educational Psychology: Effective Teaching, Effective Learning, Third Edition. Singapore: The McGrawHill Companies, Inc.

Gardner, R. 2004. Attitude/Motivation Test Battery. Western Ontario: The University of Western Ontario

Khan, A. S. 2013. Technology's Role on Students' Behavior. Department of Education, Preston University, Pakistan, Proc. 10th International Conference on Statistical Sciences, Lahore, Pakistan March 7-9, 2013, Vol. 24, pp. 13-22

Lavin, A. M., Korte, L., and Davies, T. L. 2010. The Impact of Classroom Technology on Student Behavior. September 2010, Journal of Technology Research; Sep 2010, Vol. 2, p1.

McNiff, J., \& Whitehead, J. 2002. Action Research: Principles and Practice. London: Routledge Falmer

Pang, E. S. 2003. Teaching Reading. Switzaerland: International Academy of Education

Reeve, J. 2009. Understanding Motivation and Emotion. New Jersey: John Willey \& Sons

Singh, Y., Sharma, T., \& Upadhya, B. 2008. Educational Technology: Teaching and Learning. New Delhi (India). APH Publishing Corporation. P 1-2.

Smaldino, S., Russel, J.D., Heinich, R., and Molenda, M. (2005). Instructional Technology and Media for Learning. New Jersey: Pearson Merrill Prentice Hall, Upper Saddle river/. 